« Rowdẹe-Hูāaī va rābețe-ye ān bā radîf-e mūsīqī-ye sonnatī-ye İrān ». Faṣl-nāme-ye mūsīqīye Māhūr, $\mathrm{n}^{\circ}$ 18, (hiver 2002), pp. 11-23. [Rowde- $\mathrm{H}^{\mathrm{v} a \bar{n}} \mathbf{i}$ et son rapport avec le radif de la musique traditionnelle iranienne]

\title{
Sasan Fatemi
}

\section{CpenEdition}

\section{Journals}

Édition électronique

URL : http://journals.openedition.org/abstractairanica/5286

DOI : 10.4000/abstractairanica.5286

ISSN : 1961-960X

Éditeur :

CNRS (UMR 7528 Mondes iraniens et indiens), Éditions de l'IFRI

Édition imprimée

Date de publication : 15 mai 2004

ISSN : 0240-8910

Référence électronique

Sasan Fatemi, « « Rowde-ḩvānī va rābete-ye ān bā radîf-e mūsīqī-ye sonnatī-ye Îrān ». Fașl-nāme-ye mūsíqi-ye Māhūr, n 18, (hiver 2002), pp. 11-23. [Row de-hvāāī et son rapport avec le radîf de la musique traditionnelle iranienne] », Abstracta Iranica [En ligne], Volume 25 | 2004, document 380, mis en ligne le 15 mars 2006, consulté le 25 septembre 2020. URL : http://journals.openedition.org/abstractairanica/ 5286 ; DOI : https://doi.org/10.4000/abstractairanica.5286

Ce document a été généré automatiquement le 25 septembre 2020.

Tous droits réservés 
« Row dẹe-Hु̄ānī va rābețe-ye ān bā radîf-e mūsīqī-ye sonnatī-ye İrān ». Faṣl-nāme-ye mūsīqì-ye Māhūr, $\mathrm{n}^{\circ} 18$, (hiver 2002), pp. 11-23. [Rowde- $\mathrm{H}^{\mathrm{v}}$ $\bar{a} n \overline{1}$ et son rapport avec le radíf de la musique traditionnelle iranienne]

\section{Sasan Fatemi}

Un petit article du regretté Mohammad-Taqī Mas'ūdiye qui n'avait pas été publié de son vivant. L'A. analyse un chant religieux, row dẹ-Hūānī, interprété par un des meilleurs rowde $-H^{v} \bar{a} n$ de Mašhad, enregistré en 1974. Ce chant a une particularité intéressante qui consiste en une modulation peu commune : du dastgāh-e šür au moH̄ālef de segāh (puis au matnavi-ye moHālef). Ces phases différentes du déroulement du morceau sont comparées avec leurs semblables dans le radîf instrumental de Mūsā Ma'rūfĩ et le radîf vocal de Maḥmūd Karīmī.

\section{INDEX}

Thèmes : 17.1.Musique 


\section{AUTEURS}

SASAN FATEMI

Université de Téhéran 